\title{
Effects of thermal radiation, viscous dissipation, variable magnetic field and suction on mixed convection MHD flow of nanofluid over a non-linear stretching sheet
}

\author{
Mohammad Mehdi Keshtekar ${ }^{1}$ Ahmad Khaluei ${ }^{2}$, Hadi Ameri Fard ${ }^{3}$ \\ ${ }^{I}$ Assistant Professor of Mechanical Engineering, Islamic Azad University, Kerman Branch, Iran \\ ${ }^{2,3,4}$ MS.C Student of Mechanical Engineering, Islamic Azad University, Kerman Branch, Iran
}

\begin{abstract}
In this work,mixed convection MHD flow of nanofluid over a non-linear stretching sheet with thermal radiation and suction and variable magnetic field is investigated. An analysis of the results shows that the velocity and thermal fields are influenced appreciably by the magnetic field,effective Prandtl number, local Grashof number, Eckert number, power-law stretching parameter and nanoparticles volume fraction. Solutions are presented for velocity and temperature fields for various values of magnetic field and suction parameters. Thermal boundary layer equation takes into account of viscous dissipation and Ohmic dissipation due to transverse magnetic field and electric field.
\end{abstract}

Keywords: Nanofluids, Mixed convection, Magnetic field, Thermal radiation, Viscous dissipation

\section{INTRODUCTION}

Convective heat transfer in the boundary layer flow caused by a stretching sheet is the study of extrusion processes which has attracted many researchers due to its important applications in plastic and metal industries, for example, in metallurgical processes, such as drawing stretching sheets through quiescent fluids, manufacturing of plastic and rubber sheets, continuous cooling of fiber spinning, annealing and thinning of copper wires. The study of magnetohydrodynamic (MHD) flow has many important industrial technological and geothermal applications such as high temperature plasmas, cooling of nuclear reactors, MHD accelerators and power generation systems, and liquid metal fluids. few studies have been focused on exponentially and nonlinear stretching sheet. Magyari and Kellar [1] and Elbashbeshy [2] studied heat and mass transfer in the boundary layer on an exponentially stretching sheet, whereas Vajravelu [3], Vajravelu and Cannon [4] and Cortell [5] have investigated viscous flow over a nonlinear stretching sheet. The role of thermal radiation is of major important in some industrial applications such as glass production and furnace design, and also in space technology applications, such as comical flight aerodynamics rocket, propulsion systems, plasma physics and space craft reentry aerodynamics which operates at high temperatures. Cortell [6] analyzed the effects of viscous dissipation and thermal radiation over a non-linear stretching sheet. Hady et al. [7] investigated the effects of heat transfer over a nonlinearly stretching sheet in the presence of thermal radiation a nanofluid. Vajravelu and Rollins [8] analyzed heat transfer in an electrically conducting fluid over a stretching surface taking into account the magnetic field. Hamad and Pop [9] studied theoretically the unsteady magnetohydrodynamic flow of a nanofluid past an oscillatory moving vertical permeable semi-infinite plate in the presence of constant heat source in a rotating frame of reference. Solutions are presented for velocity and temperature fields for various values of magnetic field and suction parameters.

\section{Nomenclature}

$b$ - stretching rate, positive constant; positive constant; $C p$ - specific heat at constant pressure, $\mathrm{J} /(\mathrm{kg} \mathrm{K})$; $f$ - dimensionless velocity variable; $g$ - gravitational acceleration, $\mathrm{m} / \mathrm{s} 2 ; k$ - thermal conductivity, $\mathrm{W} /(\mathrm{m} \mathrm{K}) ; \mathrm{Pr}$ Prandtl number, ; Rex - local Reynolds number, ; T - temperature variable, K; Tw - given temperature at the sheet, $\mathrm{K} ; T_{\infty}$ - temperature of the fluid far away from the sheet, $\mathrm{K} ; \Delta T$ - sheet temperature, $\mathrm{K} ; v_{\mathrm{w}}$; suctions; $u$ velocity in $\mathrm{x}$-direction, $\mathrm{m} / \mathrm{s} ; u w$ - velocity of the sheet, $\mathrm{m} / \mathrm{s} ; v$ - velocity in $\mathrm{y}$-direction, $\mathrm{m} / \mathrm{s} ; X$ - horizontal distance, $\mathrm{m} ; Y$ - vertical distance, $\mathrm{m}$; - stream function, $\mathrm{m} 2 / \mathrm{s} ; v$ - kinematic viscosity, $\mathrm{m} 2 / \mathrm{s} ; \beta$ - stretching parameter, ; $\beta f$ - thermal expansion coefficient of the basic fluid, $\mathrm{K}-1 ; \beta s$ - thermal expansion coefficient of the basic nanoparticle, $\mathrm{K}-1 ; \beta n f$ - thermal expansion coefficient of the basic nanofluid, $\mathrm{K}-1 ; \mu$ - dynamic viscosity, $\mathrm{kg} /(\mathrm{m}$ s) $\rho$ - density, $\mathrm{kg} / \mathrm{m} 3 ; \mathrm{mho} / \mathrm{s} ; \theta$ - dimensionless temperature variable, ; - solid volume fraction, (m3)s $/ \mathrm{m} 3 ; \alpha$ thermal diffusivity, $\mathrm{m} 2 / \mathrm{s} ; \rho C p$ - heat capacitance of the basic fluid, $\mathrm{J} /(\mathrm{m} 3 \mathrm{~K})$; $\mathrm{Q}$ : thermal radiation. 


\section{FLOW ANALYSIS}

The boundary layer equations of mass and momentum for the mixed convection flow and the energy equation in the presence of magnetic field, viscous dissipation and the thermal radiation are as follows:

$\frac{\partial u}{\partial x}+\frac{\partial v}{\partial y}=0$,

$\mathrm{u} \frac{\partial u}{\partial x}+\mathrm{v} \frac{\partial u}{\partial y}-\frac{\mu u}{p n f} \frac{\partial^{\mathrm{z}} u}{\partial y^{2}}+\frac{(p \beta)_{n f}}{p_{n f}} \mathrm{~g}\left(\mathrm{~T}-\mathrm{T}_{\infty}\right)-\frac{\sigma B(x)^{\mathrm{z}}}{p_{n f}} \mathrm{u}$,

$\mathrm{u} \frac{\partial T}{\partial x}+\frac{\partial T}{\partial y}=\alpha_{\mathrm{nf}} \frac{d^{2} T}{d y^{2}}-\frac{1}{\left(p c_{p}\right)_{n f}} \frac{\partial q_{Y}}{\partial y}+\frac{\mu_{n f}}{\left(p c_{p}\right)_{n f}}\left(\frac{\partial u}{\partial y}\right)^{2}$,

Subject to the boundary conditions for stretching sheet:

$\mathrm{u}=\mathrm{u}_{\mathrm{w}}(\mathrm{x})= \pm c \mathrm{x}^{\mathrm{n}}, \quad \mathrm{v}=\mathrm{v}_{\mathrm{w}}, \quad \mathrm{T}=\mathrm{T}_{\mathrm{w}}(\mathrm{x})=\mathrm{T}_{\infty}+\mathrm{bx}^{\mathrm{n}} \quad$ at $\mathrm{y}=0$

$\mathrm{u} \rightarrow 0, \mathrm{~T}=\mathrm{T} \infty$ as $\mathrm{y} \rightarrow \infty$

Where $\mathrm{c}$ is a constant having the values $\mathrm{c}>0$ for stretching sheet; $\mathrm{u}$ and $v$ are the velocity components along $\mathrm{x}$ - and $\mathrm{y}$-directions, respectively. $\mathrm{T}$ is the temperature of the nanofluid, $\mathrm{g}$ is the acceleration due to gravity, $v_{\mathrm{w}}$ is the wall mass flux with $v_{\mathrm{w}}<0$ for suctions and $v_{\mathrm{w}}>0$ for injection, respectively. Further, $\mu_{\mathrm{nf}}$ is the coefficient of viscosity of the nanofluid, (Beta) $)_{\mathrm{nf}}$ is the thermal expansion of the nanofluid, $\alpha_{\mathrm{nf}}$ is the thermal diffusivity of the nanofluid, $\rho_{\mathrm{nf}}$ is the effective density of the nanofluid, $\left(\rho \mathrm{C}_{\mathrm{p}}\right)_{\mathrm{nf}}$ is the heat capacitance of the nanofluid which are defined as follows:

$$
\begin{aligned}
& \alpha_{\mathrm{nf}}=\frac{K_{n f}}{\left(p c_{p_{p}}\right)_{n f}}, \mathrm{p}_{\mathrm{nf}}=(1-\Phi) \mathrm{p}_{\mathrm{f}}+\Phi \mathrm{p}_{\mathrm{s}}, \mu_{n f}=\frac{\mu_{f}}{(1-\Phi)^{25}}, \\
& (\mathrm{p} \beta)_{\mathrm{nf}}=(1-\Phi)(\mathrm{p} \beta)_{\mathrm{f}}+\Phi(\mathrm{p} \beta)_{\mathrm{s}} \\
& \left(\mathrm{pC}_{\mathrm{p}}\right)_{\mathrm{nf}}=(1-\Phi)\left(\mathrm{pC}_{\mathrm{p}}\right)_{\mathrm{f}}+\Phi\left(\mathrm{pC}_{\mathrm{p}}\right)_{\mathrm{s}} \\
& \frac{K_{n f}}{K_{f}}=\frac{\left(K_{s}+2 K_{f}\right)-2 \Phi\left(K_{f}-K_{s}\right)}{\left(K_{s}+2 K_{f}\right)-2 \Phi\left(K_{f}-K_{s}\right)}
\end{aligned}
$$

Where $\varphi$ is the solid volume fraction of the nanofluid, $\rho_{\mathrm{f}}$ is the reference density of the fluid fraction, $\rho_{\mathrm{s}}$ is the reference density of the solid fraction, If is the viscosity of the fluid fraction, $\beta_{\mathrm{f}}$ thermal expansion coefficient of the fluid, $\beta_{\mathrm{s}}$ thermal expansion coefficient of the nanoparticles, $\mathrm{k}_{\mathrm{f}}$ is the thermal conductivity of the fluid, $\mathrm{k}_{\mathrm{s}}$ is the thermal conductivity of the solid fraction and $\mathrm{k}_{\mathrm{nf}}$ is the thermal conductivity of the nanofluid. The Rosseland approximation $[10]$ applied to optically thick media and the net radiation heat flux $\mathrm{qr}^{[}\left[\mathrm{W} \mathrm{m}^{-2}\right]$ by the expression:

$\mathrm{q}_{\mathrm{r}}=-\frac{4}{3 k^{2}} \operatorname{grad}\left(e_{b}\right)$,

Where $\mathrm{k}^{*}\left[\mathrm{~m}^{-1}\right]$ is the Rosseland mean spectral absorption coefficient and $\mathrm{e}_{\mathrm{b}}\left[\mathrm{W} \mathrm{m} \mathrm{m}^{-2}\right]$ is the blackbody emission power which is given in terms of the absolute temperature T by the Stefan-Boltzmann radiation law $\mathrm{e}_{\mathrm{b}}$ $=\sigma^{*} \mathrm{~T}^{4}$ with the Stefan-Boltzmann constant $\sigma^{*}=5.6697 \times 10^{-8} \mathrm{Wm}^{-2} \mathrm{k}^{-4} \mathrm{It}$ is further assumed that the term T4 due to radiation within the flow can be expressed as a linear function of temperature itself. Hence $\mathrm{T}^{4}$ can be expanded as Taylor series about $\mathrm{T} \infty$ and can be approximated after neglecting the higher order terms as:

$$
\mathrm{T}^{4} \approx 4 T_{\infty}^{3} \mathrm{~T}-3 T_{\infty}^{4} \text {. }
$$

$\frac{\mathrm{d} q r}{\mathrm{~d} y}=-\frac{16 \sigma^{*} T_{\infty}^{\mathrm{s}}}{3 K^{*}} \frac{\mathrm{d}^{2} T}{\mathrm{~d} y^{2}}$.

We now look for a similarity solution of the Eqs. (1)-(3) with boundary conditions (4) and (5) using the following Transformation

$$
\left[\frac{(m+1) u_{w}(x)}{2 v_{f} x}\right]^{1 / 2} \mathrm{y} \cdot=\left[\frac{2 v_{f} x u_{w}(x)}{(m+1)}\right]^{1 / 2} \mathrm{f}(\eta), \eta \psi=
$$


Table 1Therm ophysical properties of fluid and nanopartides

$\theta(\eta)=\frac{T-T_{\infty}}{T_{w}-T_{\infty}}, n=2 m$, Substituting Eqs. (6)-(12) into Eqs. (2) and (3), we get the following nonlinear ordinary differential equations:

$$
\begin{aligned}
& F^{I W}+(1-\Phi)^{25}\left\{\left(1-\Phi+\Phi \frac{p_{g}}{p_{f}}\right)\left(\mathrm{FF}^{\prime \prime}-\frac{2 m}{m+1} F^{\prime 2}\right)\right. \\
& \left.-\mathrm{M} F^{\prime}+\frac{2 m}{m+1}\left(1-\Phi+\Phi \frac{(p \beta)_{s}}{(p \beta)_{f}}\right) R i \theta\right\}=0, \\
& \frac{1}{\mathrm{p}_{\mathrm{r} \theta \mathbb{J}}} \theta^{\sigma}+\left(1-\Phi+\Phi \frac{\left(p C_{p}\right)_{s}}{\left(p C_{p}\right)_{f}}\right)\left(\mathrm{F} \theta^{\sigma}-\frac{4 m}{m+1} F^{\prime} \theta\right)+\frac{E c}{(1-\Phi)^{2 s}}\left(\mathrm{~F}^{\prime \prime}\right)^{2}=0 \\
& \mathrm{~F}=\mathrm{S}, \quad \hat{F}= \pm 1 . \quad 0=1 \text { at } \eta=0 \\
& \hat{F} \rightarrow 0, \theta \rightarrow 0 \text { as } \eta \rightarrow \infty \text {, } \\
& \mathrm{f}_{\mathrm{\eta}}(0)=1, \mathrm{f}(0)=0, \theta(0)=1 \\
& \mathrm{f}_{\eta}(\infty)=0, \quad \theta(\infty)=0
\end{aligned}
$$

On the other hand:

$$
\begin{aligned}
& \operatorname{Pr}=\frac{\mu C_{p}}{k}=\frac{v_{f}}{a_{f}} i \\
& \mathrm{M}=\frac{2 \sigma B_{0}^{2}}{C(m+1) p_{f}}, \\
& \operatorname{Ri}=\frac{G r}{R \theta_{x}^{2}} \quad G r=\frac{g \beta\left(T_{w}-T_{\infty}\right) x^{g}}{v_{f}^{2}} \quad \mathrm{Nr}=-\frac{16 \sigma^{*} T^{g}}{3 k_{f} k^{*}} \\
& \operatorname{Pr}_{\text {eff }}=\frac{p_{r}}{\frac{k_{n f}}{k_{f}}+N r} \quad \mathrm{Ec}=\frac{c^{2}}{b\left(C_{p}\right)_{f}} \\
& \mathrm{C}_{\mathrm{f}}=\frac{\mu_{n f}}{p_{f} u_{w}^{2}}\left(\frac{\vartheta T)}{\vartheta_{y}}\right)_{y-0} \quad \mathrm{Nux}=\frac{-x K_{n f}}{K_{f}\left(T_{w}-T_{\infty}\right)}\left(-\frac{\vartheta T)}{\vartheta y}\right)_{y-0}
\end{aligned}
$$

The local skin friction coefficient and the local Nusselt number can be expressed as:

$$
\begin{aligned}
& \mathrm{Re}_{x}^{1 / 2} \mathrm{C}_{\mathrm{f}}=\frac{1}{(1-\Phi)^{2 \cdot 5}}\left(\frac{m+1}{2}\right)^{1} \hat{F}(0), \\
& \operatorname{Re}_{x}^{1 / 2} \mathrm{Nu}_{\mathrm{x}}=-\frac{k_{n f}}{k_{f}}\left(\frac{m+1}{2}\right)^{\frac{1}{2}} \hat{\theta}(0)
\end{aligned}
$$

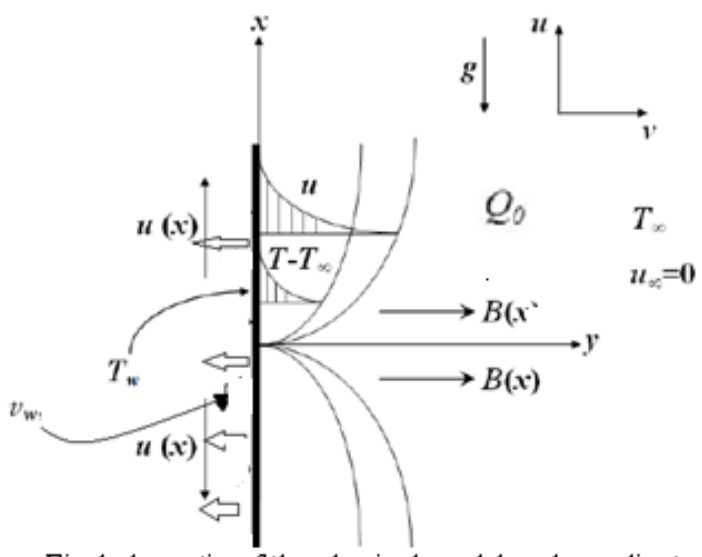

Fig.1 shematic of the physical model and coordinate system

$$
\text { III. RESULTS AND DISCUSSION }
$$


Effects of thermal radiation, viscous dissipation, variable magnetic field and suction on mixed

\begin{tabular}{l|l|l|l|l}
\hline $\begin{array}{l}\text { Physical } \\
\text { Properties }\end{array}$ & $\begin{array}{l}\text { Fluid phase } \\
\text { (water) }\end{array}$ & $\begin{array}{l}\text { Cop per } \\
(\mathrm{Cu})\end{array}$ & $\begin{array}{l}\text { Alumina } \\
\left(\mathrm{Al}_{2} \mathrm{O}_{3}\right)\end{array}$ & $\begin{array}{l}\text { Titanium } \\
\left(\mathrm{TiO}_{2}\right)\end{array}$ \\
\hline $\mathrm{C}_{\mathrm{p}}(1 / \mathrm{kg} \mathrm{k})$ & 4179 & 385 & 765 & 686.2 \\
$\mathrm{P}\left(\mathrm{kg} / \mathrm{m}^{3}\right)$ & 997.1 & 8933 & 3970 & 4250 \\
$\mathrm{~K}(\mathrm{~W} / \mathrm{m} \mathrm{k})$ & 0.613 & 400 & 40 & 8.9538 \\
$\beta \times 10^{5}\left(\mathrm{k}^{-1}\right)$ & 21 & 1.67 & 0.85 & 0.9 \\
\hline
\end{tabular}

In Tables, thermal properties of nanoparticles of the present work are seen. Also, and show the values of Nusselt number and stretching sheet friction co-efficient for different governed physical parameters and different nanoparticles.

Table2Comparition of results for $-F^{\circ}(0)$ when $\Phi=\mathrm{M}=\mathrm{Ri}=0$ in absence of thermal radition

\begin{tabular}{l|l}
\hline $\mathrm{m}$ & Present results \\
\hline & \\
0.0 & 0.6275 \\
0.2 & 0.7668 \\
0.5 & 0.8895 \\
1.0 & 1.000 \\
3.0 & 1.1486 \\
10.0 & 1.2348 \\
20.0 & 1.2574 \\
\hline
\end{tabular}

Table 3 Comparition of results for $-\mathrm{g}(0)$ when $\Phi=\mathrm{M}=\mathrm{Ri}$ $=0$ and $\operatorname{pr}(-\mathrm{pr})-5$ for stretching

\begin{tabular}{l|l|l}
\hline $\mathrm{m}$ & $\begin{array}{l}\text { Ec }-\mathrm{O} \\
\text { present } \\
\text { results }\end{array}$ & $\begin{array}{l}\frac{\text { Bc- } 0.1}{\text { present }} \\
\text { results }\end{array}$ \\
\hline 0.75 & 3.1253 & 3.0156 \\
1.50 & 3.5679 & 3.4566 \\
7.00 & 4.1854 & 4.0695 \\
10.0 & 4.2559 & 4.1354 \\
\hline
\end{tabular}

Table4 Values of $\mathrm{p}(0)$ and $\mathrm{g}(0)$ for the nanofluid $(\mathrm{Cu}$ - water) with different values of $\mathrm{m}, \Phi, \mathrm{M}, \mathrm{Ri}, \mathrm{Ec}, \mathrm{Ec}, \mathrm{pr}^{*}$ and $\mathrm{s}$.

\begin{tabular}{|c|c|c|c|c|c|c|c|c|}
\hline \multirow{2}{*}{$\mathrm{m}$} & \multirow{2}{*}{$*$} & \multirow{2}{*}{ M } & \multirow{2}{*}{$\mathrm{Ri}$} & \multirow{2}{*}{ Ec } & \multirow{2}{*}{$\mathrm{pr}$} & \multirow[b]{2}{*}{$\mathrm{S}$} & \multicolumn{2}{|c|}{ stretching sheet } \\
\hline & & & & & & & $p^{-(0)}$ & $-y(0)$ \\
\hline 1 & 0.0 & 0.1 & 0.1 & 0.01 & & & $\begin{array}{l}- \\
1.0271\end{array}$ & 2.3838 \\
\hline \multirow[t]{8}{*}{2} & & & & & & & $\begin{array}{l}- \\
1.1787\end{array}$ & 2.6631 \\
\hline & 0.1 & & & & & & $\begin{array}{l}- \\
0.9761\end{array}$ & 2.0238 \\
\hline & 0.2 & & & & & & $\overline{-}-9723$ & 1.5020 \\
\hline & & 0.2 & & & & & $\begin{array}{l}- \\
0.8283\end{array}$ & 1.4918 \\
\hline & & 0.3 & & & & & $\begin{array}{l}- \\
0.8628\end{array}$ & 1.4820 \\
\hline & & & 0.2 & & & & $\begin{array}{l}- \\
0.8496\end{array}$ & 1.4850 \\
\hline & & & 0.3 & & & & $\overline{-} 0.8366$ & 1.4880 \\
\hline & & & & 0.05 & & & - & 1.4693 \\
\hline
\end{tabular}


Effects of thermal radiation, viscous dissipation, variable magnetic field and suction on mixed

\begin{tabular}{l|l|l|l|l|l|l|l|l}
\hline & & & & & & & 0.8362 & \\
\hline & & & & 0.10 & & & $\begin{array}{l}- \\
0.8358\end{array}$ & 1.4460 \\
\hline & & & & & 3.0 & & $\begin{array}{l}- \\
0.8389\end{array}$ & 1.6065 \\
\hline & & & & & 3.5 & & $\begin{array}{l}- \\
0.8413\end{array}$ & 1.7548 \\
\hline & & & & & & 0.2 & $\begin{array}{l}- \\
0.8651\end{array}$ & 1.8149 \\
\hline 2 & 0.2 & 0.3 & 0.3 & 0.10 & 3.5 & 0.3 & - & 0.8896 \\
\hline
\end{tabular}

Table5 $(\mathrm{Pr}=6.2)$ at $\mathrm{Ec}=0, \quad \mathrm{Mn}=0$,

$\mathrm{Gr} / \mathrm{Re}^{2}=1, \beta=1$

\begin{tabular}{|l|l|l|l|}
\cline { 3 - 4 } \multicolumn{1}{c|}{} & \multirow{2}{c|}{$\Phi$} & $f_{\text {ov }}(0)$ & $-\theta_{\pi}(0)$ \\
\cline { 3 - 4 } \multicolumn{1}{c|}{} & $\begin{array}{l}\text { Present } \\
\text { results }\end{array}$ & $\begin{array}{l}\text { Present } \\
\text { results }\end{array}$ \\
\hline $\mathrm{Al}_{2} \mathrm{O}_{3}$ & 0.0 & 0.4389 & 0.8876 \\
$\mathrm{Ag}$ & 0.2 & 0.3208 & 0.7164 \\
& 0.0 & 0.4396 & 0.9017 \\
$\mathrm{Cu}$ & 0.2 & 0.3084 & 0.7156 \\
& 0.0 & 0.4401 & 0.9511 \\
& 0.2 & 0.3072 & 0.8510 \\
\hline
\end{tabular}

Table6Thermo-physical properties of water and nonparticles

\begin{tabular}{|c|c|c|c|c|c|c|c|}
\hline physical peoperties & $\begin{array}{l}\begin{array}{l}\text { Fluid } \\
\text { (water) }\end{array} \\
\end{array}$ & $\mathrm{SiO}_{2}$ & $\mathrm{Cu}$ & $\mathrm{Ag}$ & $\mathrm{Al}_{2} \mathrm{O}_{3}$ & $\mathrm{TiO}_{2}$ & $\mathrm{CuO}$ \\
\hline $\begin{array}{l}\mathrm{P}, \mathrm{kgm}^{-3} \\
\mathrm{C}_{\mathrm{p}}, \mathrm{Jkg}^{-1} \mathrm{~K}^{-1} \\
\beta \times 10^{5}, \mathrm{~K}^{-1} \\
\mathrm{k}, \mathrm{Wm}^{-1} \mathrm{~K}^{-1}\end{array}$ & $\begin{array}{l}997.1 \\
4179 \\
21.0 \\
0.613\end{array}$ & $\begin{array}{l}3970 \\
765 \\
0.63 \\
36.0\end{array}$ & $\begin{array}{l}8933 \\
385 \\
1.67 \\
401\end{array}$ & $\begin{array}{l}10500 \\
235 \\
1.89 \\
429\end{array}$ & $\begin{array}{l}3970 \\
765 \\
0.85 \\
40\end{array}$ & $\begin{array}{l}4250 \\
686.2 \\
0.90 \\
8.9538\end{array}$ & $\begin{array}{l}6500 \\
540 \\
0.85 \\
18.0\end{array}$ \\
\hline
\end{tabular}

Table7 Skin friction coefficient and Nusselt number for different values of the physical parameters. $\mathrm{SiO}_{2} \mathrm{WATER}_{\mathrm{N}} \mathrm{Pr}=6.2$

\begin{tabular}{|c|c|c|c|c|c|c|c|c|c|}
\hline$\Phi$ & $\beta$ & Ec & Mn & \multicolumn{2}{|c|}{$\mathbf{G r} / \operatorname{Re}^{2} \ll<1$} & \multicolumn{2}{|c|}{$\mathrm{Gr} / \operatorname{Re}^{2}=1$} & \multicolumn{2}{|c|}{$\mathrm{Gr} / \operatorname{Re}^{2} \gg 1$} \\
\hline & & & & $C_{f}$ & $\mathrm{Nu}$ & $C_{f}$ & $\mathrm{Nu}$ & $C_{f}$ & $\mathrm{Nu}$ \\
\hline 0.2 & 1 & 0.02 & $\begin{array}{l}0.50 \\
0.75 \\
1.0\end{array}$ & $\begin{array}{l}0.0949 \\
0.1009 \\
0.1065\end{array}$ & $\begin{array}{l}6.6746 \\
7.9201 \\
9.1075\end{array}$ & $\begin{array}{l}0.0696 \\
0.0776 \\
0.0849\end{array}$ & $\begin{array}{l}7.4707 \\
8.8525 \\
10.1115\end{array}$ & $\begin{array}{l}0.0011 \\
0.0120 \\
0.0234\end{array}$ & $\begin{array}{l}8.9152 \\
10.6034 \\
12.0412\end{array}$ \\
\hline$\Phi$ & $\beta$ & Mn & Ec & $C_{f}$ & $\mathrm{Nu}$ & $C_{f}$ & $\mathrm{Nu}$ & $\mathrm{C}_{\mathrm{f}}$ & $\mathrm{Nu}$ \\
\hline 0.2 & 1.0 & 1.0 & $\begin{array}{l}0 \\
0.10 \\
0.20\end{array}$ & $\begin{array}{l}0.1065 \\
0.1064 \\
0.1063\end{array}$ & $\begin{array}{l}9.6732 \\
6.8553 \\
4.0472\end{array}$ & $\begin{array}{l}0.0850 \\
0.0844 \\
0.0837\end{array}$ & $\begin{array}{l}10.5207 \\
8.5015 \\
6.5427\end{array}$ & $\begin{array}{l}0.0238 \\
0.0217 \\
0.0198\end{array}$ & $\begin{array}{l}12.2357 \\
11.2921 \\
10.4268\end{array}$ \\
\hline$\Phi$ & Ec & Mn & $\beta$ & $\mathrm{C}_{\mathrm{f}}$ & $\mathrm{Nu}$ & $\mathrm{C}_{\mathrm{f}}$ & $\mathrm{Nu}$ & $\mathrm{C}_{\mathrm{f}}$ & $\mathrm{Nu}$ \\
\hline 0.2 & 0.02 & 1.0 & $\begin{array}{l}-1.0 \\
0.0 \\
1.0\end{array}$ & $\begin{array}{l}0.0251 \\
0.0579 \\
0.1065\end{array}$ & $\begin{array}{l}5.6558 \\
6.8273 \\
9.1075\end{array}$ & $\begin{array}{l}0.0087 \\
0.0398 \\
0.0849\end{array}$ & $\begin{array}{l}6.7544 \\
7.6005 \\
10.1115\end{array}$ & $\begin{array}{l}0.0485 \\
0.0119 \\
0.0234\end{array}$ & $\begin{array}{l}7.9912 \\
9.0457 \\
12.0412\end{array}$ \\
\hline $\boldsymbol{\beta}$ & Ec & Mn & $\Phi$ & $C_{f}$ & $\mathrm{Nu}$ & $C_{f}$ & $\mathrm{Nu}$ & $C_{f}$ & $\mathrm{Nu}$ \\
\hline 1 & 0.02 & 1.0 & $\begin{array}{l}0.0 \\
0.1 \\
0.2\end{array}$ & $\begin{array}{l}0.01065 \\
0.0955 \\
0.0831\end{array}$ & $\begin{array}{l}9.1075 \\
7.2426 \\
5.8316\end{array}$ & $\begin{array}{l}0.0849 \\
0.0793 \\
0.0716\end{array}$ & $\begin{array}{l}10.1115 \\
7.8262 \\
6.0776\end{array}$ & $\begin{array}{l}0.0234 \\
0.0813 \\
0.0366\end{array}$ & $\begin{array}{l}12.0412 \\
9.0896 \\
6.6858\end{array}$ \\
\hline
\end{tabular}


Effects of thermal radiation, viscous dissipation, variable magnetic field and suction on mixed

Table8 Skin friction coefficient and Nusselt number for different values of the physical parameters and different kind of nano-particles. $M n=1.0, \operatorname{Pr}=6.2, \beta=1.0, \Phi=0.20$

\begin{tabular}{|c|c|c|c|c|c|c|}
\hline & \multicolumn{2}{|c|}{$\mathrm{Gr} / \operatorname{Re}^{2} \ll 1$} & \multicolumn{2}{|c|}{$\mathrm{Gr} / \mathrm{Re}^{2}=1$} & \multicolumn{2}{|c|}{$\mathrm{Gr} / \mathrm{Re}^{2} \gg 1$} \\
\hline & $C_{f}$ & $\mathrm{Nu}$ & $C_{f}$ & $\mathrm{Nu}$ & $C_{f}$ & $\mathrm{Nu}$ \\
\hline Water & 0.1039 & 3.8975 & 0.0602 & 8.6312 & -0.0614 & 11.6052 \\
\hline $\mathrm{SiO}_{2}$ & 0.1007 & 2.6564 & 0.0661 & 6.2364 & -0.0296 & 9.5413 \\
\hline $\mathrm{Cu}$ & 0.1143 & 1.5406 & 0.0793 & 5.3308 & -0.0159 & 9.2215 \\
\hline $\mathrm{Ag}$ & 0.1182 & 1.1091 & 0.0828 & 4.9909 & -0.0131 & 9.0091 \\
\hline $\mathrm{Al}_{2} \mathrm{O}_{3}$ & 0.1007 & 2.6631 & 0.0659 & 6.2476 & -0.0301 & 9.5323 \\
\hline $\mathrm{TiO}_{2}$ & 0.1016 & 2.4820 & 0.0670 & 6.2252 & -0.0283 & 9.7045 \\
\hline $\mathrm{CuO}$ & 0.1079 & 2.0169 & 0.0738 & 5.7444 & -0.0196 & 9.5077 \\
\hline
\end{tabular}

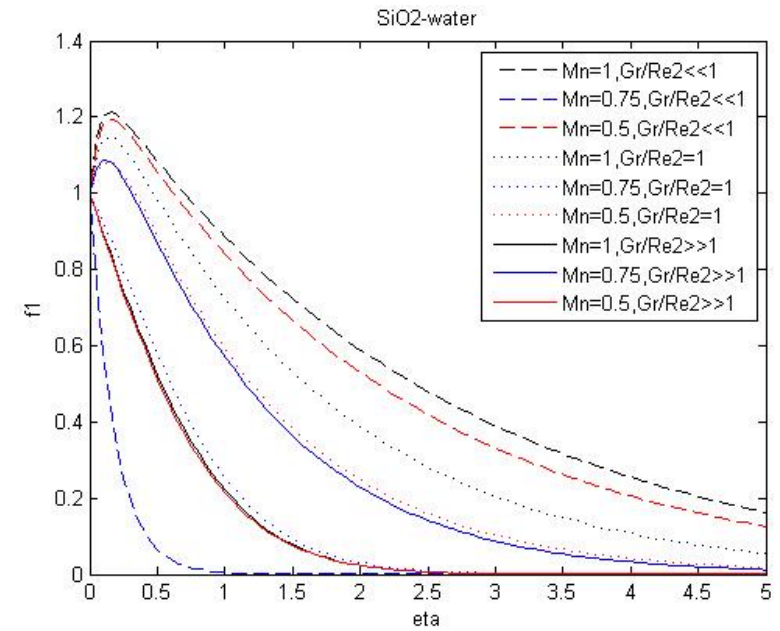

Fig. 2. Variation of velocity profiles for different types of nanofluids

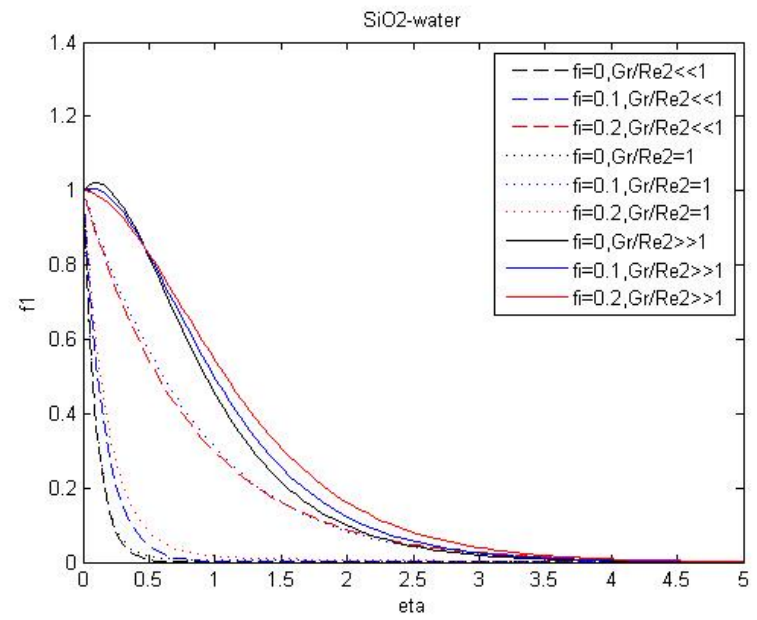

Fig. 3. Variation of velocity profiles for different types of nanofluids 


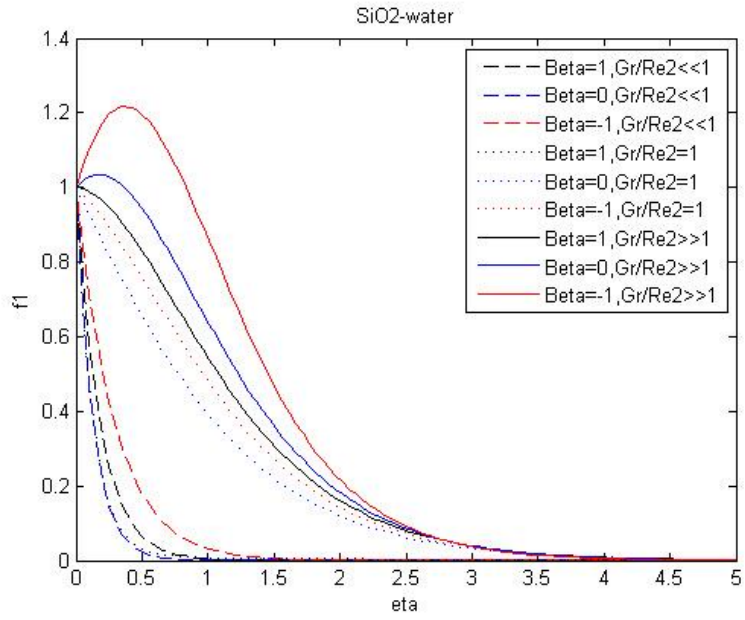

Fig. 4. Variation of velocity profiles for different types of nanofluids

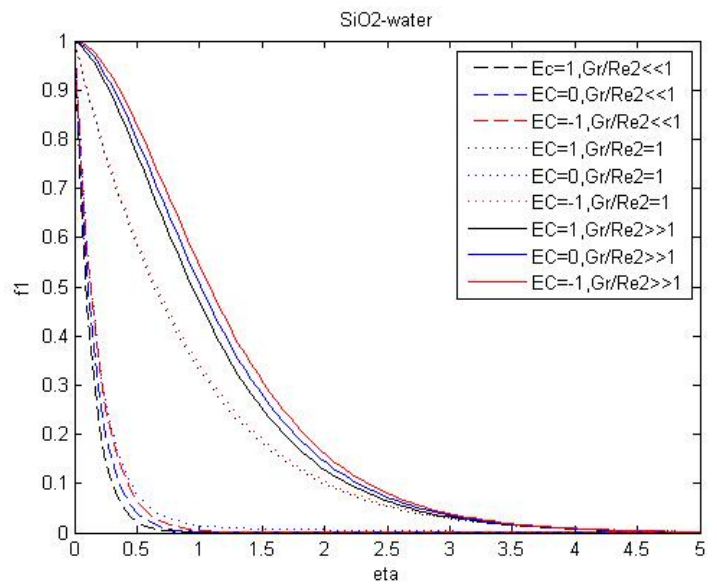

Fig. 5. Variation of velocity profiles for different types of nanofluids $\mathrm{GR}^{2}{ }^{2} \gg>1$

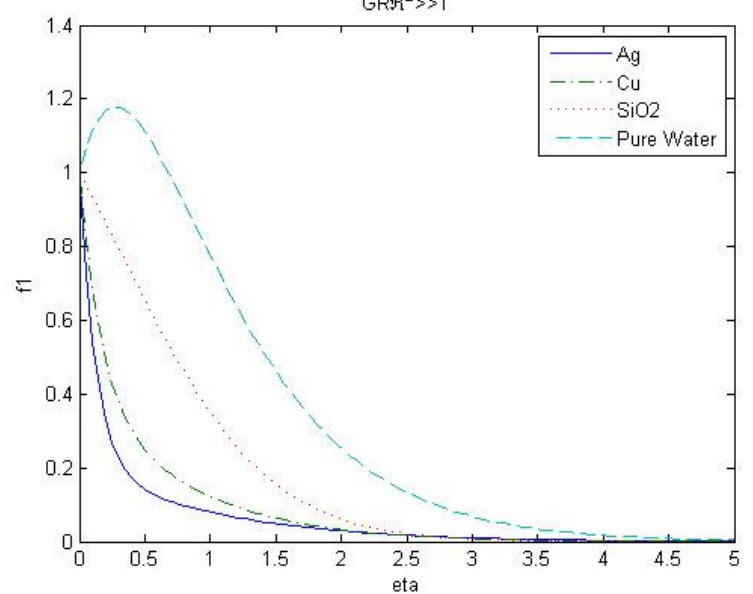

Fig. 6. Variation of velocity profiles for different types of nanofluids 


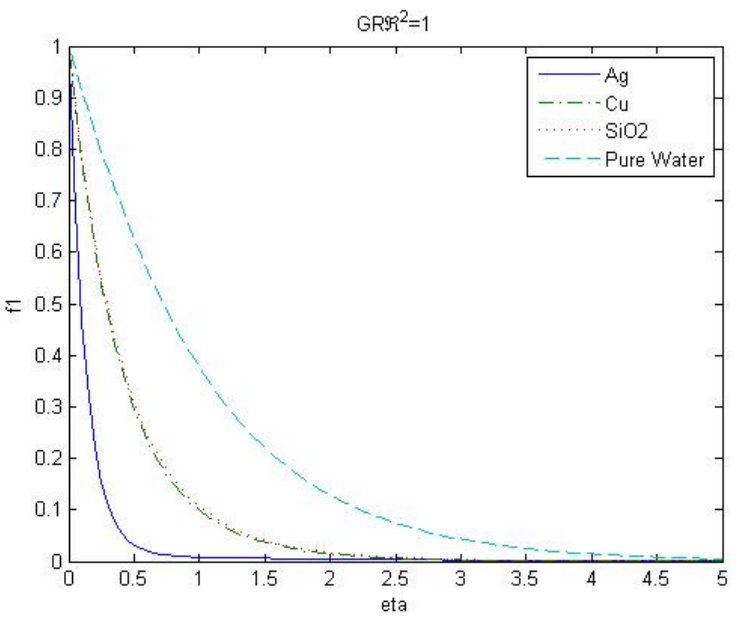

Fig. 7. Variation of velocity profiles for different types of nanofluids

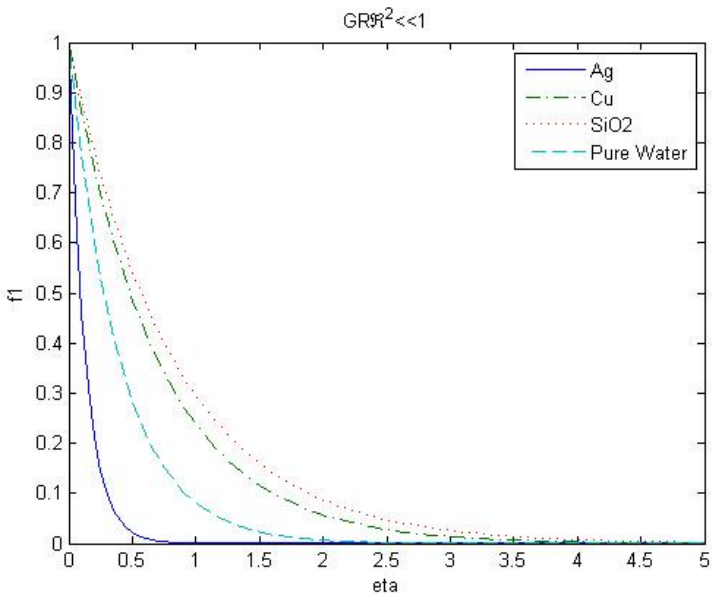

Fig. 8. Variation of velocity profiles for different types of nanofluids

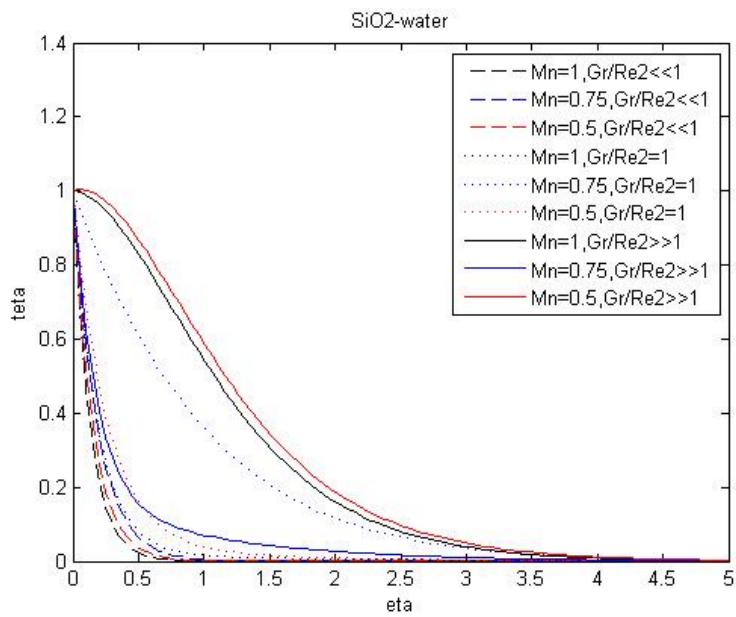

Fig. 9. Variation of temperature profiles for different types of nanofluids 


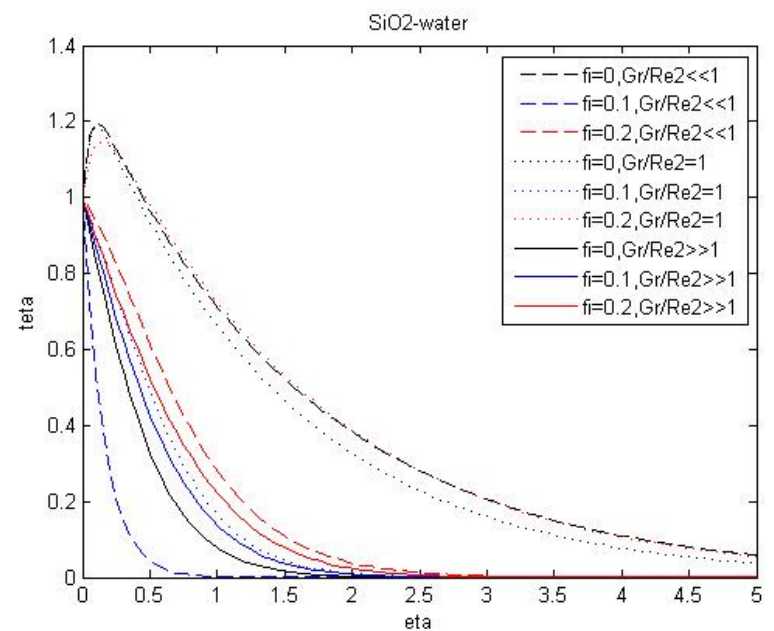

Fig. 10. Variation of temperature profiles for different types of nanofluids

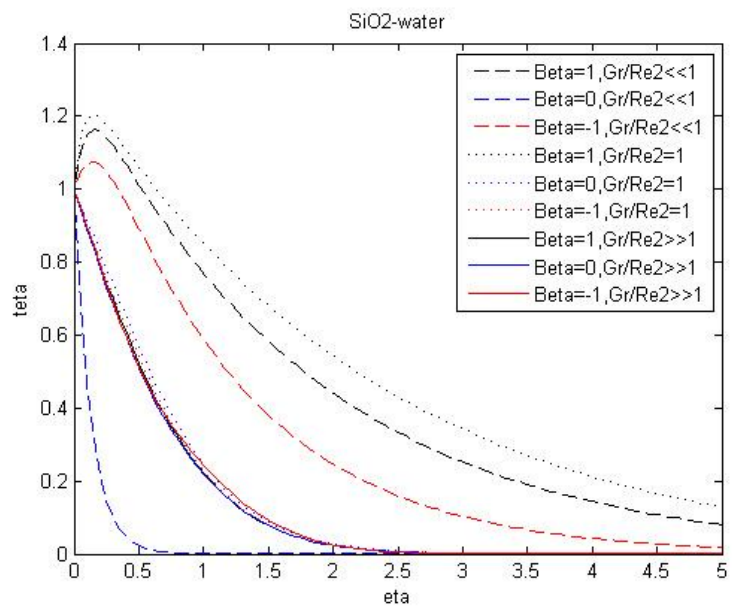

Fig. 11. Variation of temperature profiles for different types of nanofluids

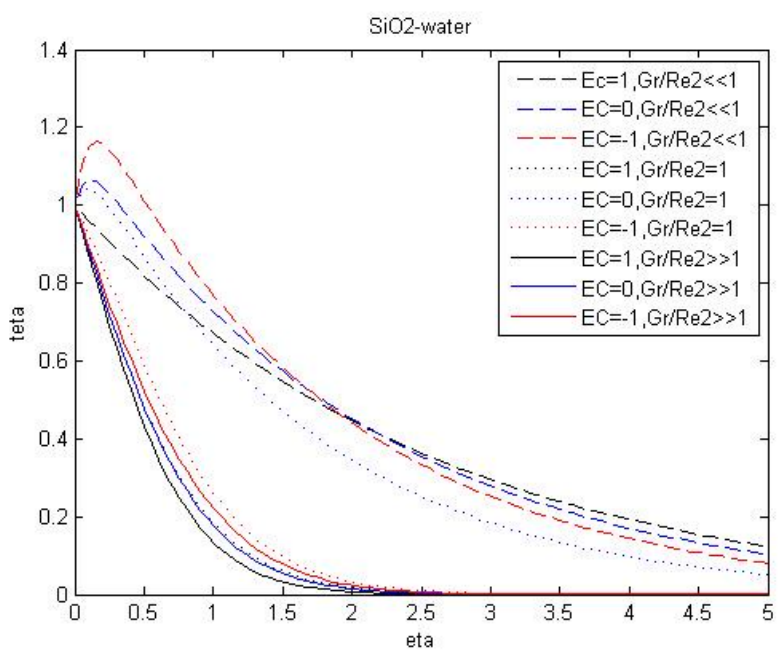

Fig. 12. Variation of temperature profiles for different types of nanofluids 


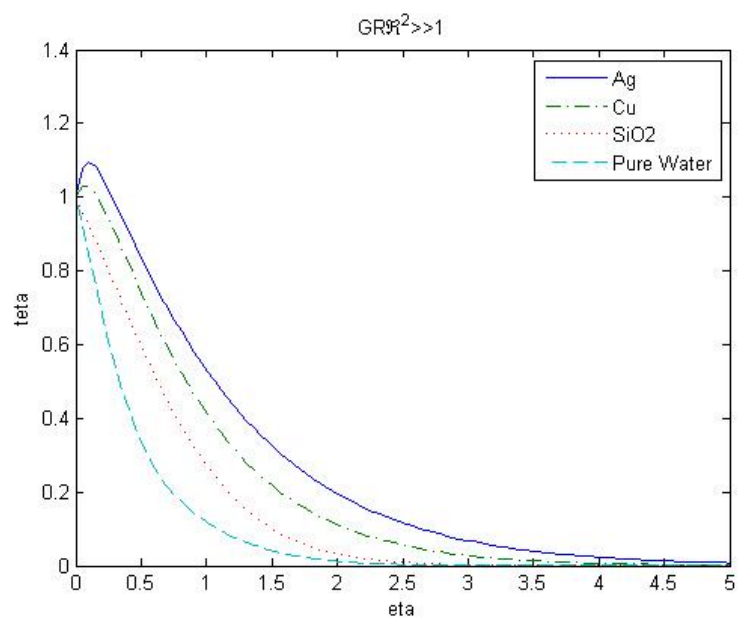

Fig. 13. Variation of temperature profiles for different types of nanofluids

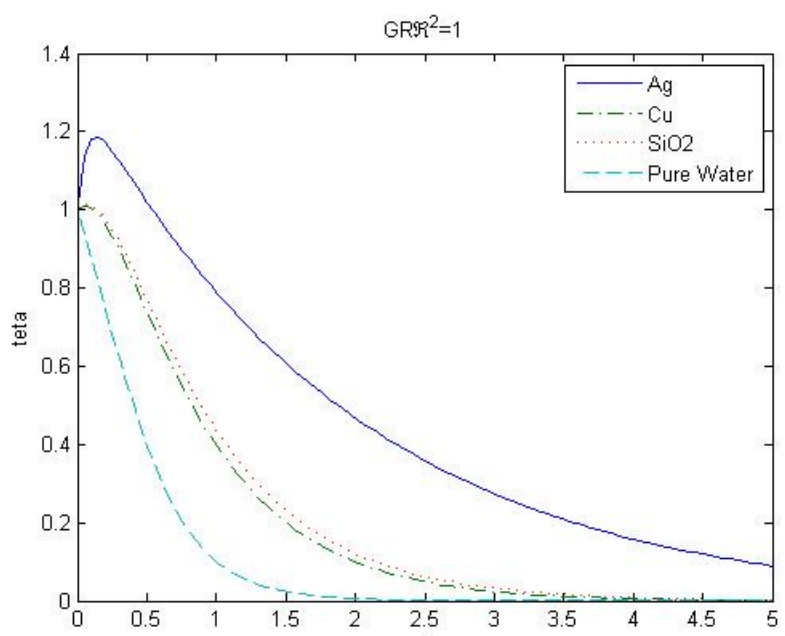

Fig. 14. Variation of temperature profiles for different types of nanofluids

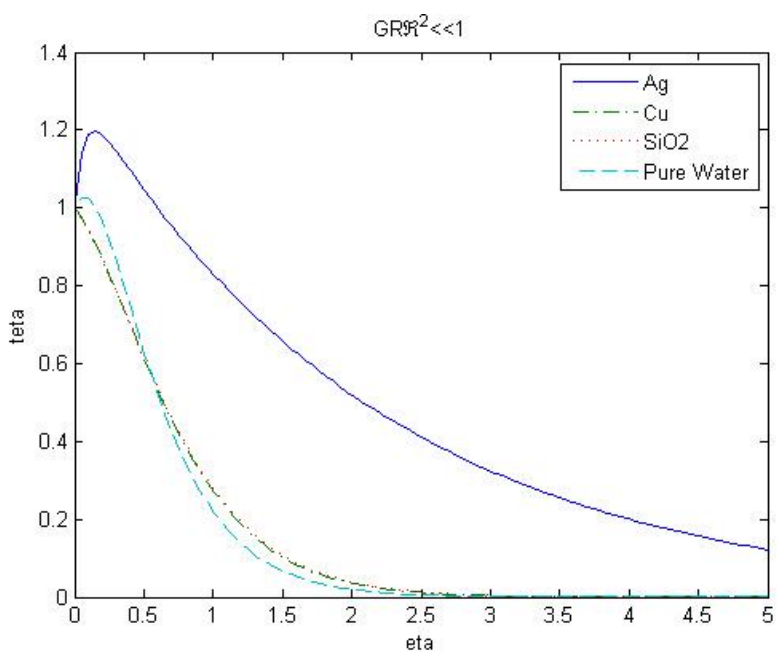

Fig. 15. Variation of temperature profiles for different types of nanofluids

It is observed from the Figs. 7 and 8 that an increase in the buoyancy parameter $\mathrm{Ri}$ for $\mathrm{M}$ and $\mathrm{Pr}$ for $\mathrm{Cu}-$ water nanofluid, there is an increase in the velocity profile in the momentum boundary layer whereas reverse effect is seen on temperature profile which decreases in the thermal boundary layer for the case of stretching sheet. The effects of $\mathrm{Ri}$ is not very prominent for both velocity and temperature fields. Fig. 12 shows the variation of temperature in-crease in $E c$ number caused the increase in fluid temperature. Because, the higher the $E c$ number, 
the higher the viscous dissipation effect in thermal boundary layer. Fig. 10 shows the variation of $\mathrm{SiO} 2$ volume frac-tion on the temperature distribution for different Richard-son numbers. Figs. 6-8 show, velocity distribution profiles for various three types of used nanoparticles such as $\mathrm{Cu}, \mathrm{Ag}, \mathrm{SiO} 2$ and pure water. In these figures, it is obvious that, boundary layer thickness changes with the change of nanoparticle type.

\section{CONCLUSION}

(1) Velocity and temperature profiles both decrease for stretching sheet in the boundary laylt is observed from the Figs. 7 and 8 that an increase in the buoyancy parameter Ri for $\mathrm{M}$ and $\mathrm{Pr}$ for $\mathrm{Cu}$-water nanofluid, there is an increase in the velocity profile in the momentum boundary layer whereas reverse effect is seen on temperature profile which decreases in the thermal boundary layer for the case of stretching sheet. The effects of Ri is not very prominent for both velocity and temperature fields.er.

(2) Velocity profile decreases and temperature profile increases with the increase in $\mathrm{M}$ for stretching sheet.

(3) Velocity profile increases but temperature profile decreases for stretching sheet.

(4) The thermal radiation, the heat generation/absorption and the permeability parameters while it decreases with an increase in the Prandtl number, the unsteadiness, the suction and the magnetic parameters.

\section{REFERENCES}

[1] Magyari, B. Keller, Heat mass transfer in the boundary layer on an exponentially stretching sheet, J. Phys. D: Appl. Phys. 32 (1999) 577-585.

[2] E.M.A. Elbashbeshy, Heat transfer over an exponentially stretching continuous surface with suction, Arch. Mech. 53 (6) (2001) 643-651.

[3] K. Vajravelu, Viscous flow over a nonlinear stretching sheet, Appl. Math. Comput. 124 (2001) 281-288.

[4] K. Vajravelu, J.R. Cannon, Fluid flow over a nonlinear stretching sheet, Appl. Math. Comput. 181 (2006) 609-628.

[5] R. Cortell, Viscous flow and heat transfer over a nonlinearly stretching sheet, Appl. Math. Comput. 184 (2007) 864-873.

[6] [6] S.U.S. Choi, Enhancing thermal conductivity of fluids with nanoparticles, in :The Proceedings the ASME International Mechanical Engineering Congress and Exposition, ASME Fluids Eng. Div., vol. 231/MD, no. 66, San Fransisco, USA 1995 ,pp. 99-105.

[7] F.M. Hady, F.S. Ibrahim, S.M. Abdel-Gaied, Md. R. Eid, Radiation effect on viscous flow of a nanofluid and heat transfer over a nonlinearly stretching sheet, Nanoscale Res. Lett. 7 (2012) 229. 13 pages.

[8] K. Vajravelu, D. Rollins, Heat transfer in electrically conducting fluid over a stretching sheet, Int. J. Nonlinear Mech. 27 (2) (1992) 265-277.

[9] M.A.A. Hamad, I. Pop, Unsteady MHD free convection flow past a vertical permeable flat plate in a rotating frame of reference with constant heat source in a nanofluid, Heat Mass Transfer 47 (2011) 15171524.

[10] E. Magyari, A. Pantokratoras, Note on the effect of thermal radiation in the linearized Rosseland approximation on the heat transfer characteristic of various boundary layer flow, Int. Commun. Heat Mass Transfer 38 (2011) 554- 556. 